\title{
Peer Observation of Teaching: Pre-Service Teachers' Perspectives for Better Performance
}

\author{
Fika Megawati \\ Fakultas Keguruan dan Ilmu Pendidikan \\ Universitas Muhammadiyah Sidoarjo \\ Sidoarjo, Indonesia \\ fikamegawati@umsida.ac.id
}

\begin{abstract}
Microteaching course is designed to accommodate teaching practice in response to the fact that pre-service teachers need supervision to overcome their anxiety when facing the real teaching situation in addition to handling classroom management and preparation. This study aims to explore the students' perspective and experience towards the non-threatening and meaningful situation in Peer Observation of Teaching (POT), specifically Peer Review model during microteaching performance. The research involved five sixth grade pre-service teachers from English Education study program. Data were collected qualitatively via observations, peer-evaluation papers and self-analysis reports. All transcripts and written samples were inductively analyzed. Findings indicate how well the preservice teachers undergo the learning process in improving the quality of teaching skill in accordance to the good and bad situation they found during the teaching simulation as the teacher, observer, and student. Accordingly, this study implies that the role of peer in this practice is highly significant in terms of building confidence as well as supportive and respectful environment to achieve better performance in teaching.
\end{abstract}

Keywords - microteaching; peer review model; English education

\section{INTRODUCTION}

In pedagogical activities, teaching skill with more realistic framework outline is the expected target of learning objective [1]. In the context of English teaching, it makes the teachers try to achieve adequate competence in teaching profession as well as English proficiency. It is not something new that English is used in everyday communication with various styles in the work place or school that demands to use it, especially to communicate with foreigners. However, for some facts, English in Indonesian education has not been exposed at that maximal point such as in their academic writing quality. For the areas that do not hav e more English exposure since they are not the center or tourism place, business, or other reasons, they know English limitedly. This condition becomes the concern of English educators in higher education level to consider more carefully to the curriculum design of microteaching course in giving pre-service teachers meaningful experience for their quality of teaching practice in both the primary and secondary schools with English as the target language during the instruction [2].
Teaching how to teach is challenging since the studentsteachers are still inexperienced, and most of them tend to have high anxiety to their first teaching practice due to some causing internal and external factors such as less teaching skill, low language mastery, worries about students response and question, low self-confidence and class-preparation [3][4][5]. The mentioned reasons are the basis of an education institution to train the student teachers in applying all theoretical understanding of English they have learned into formal teaching activities, so-called microteaching course. It is the first moment for the teacher candidates to practice teaching before they go to the real class. The teaching performance will demonstrate around 20, 30 to 40 minutes in one session. The methods of micro teaching itself also vary, and one of them is POT. Inside this POT model there is also Peer Review model or the simple name is Peer-teaching [6][7].

There are three important points to highlight in peer review of teaching process. The word "peer", "observation", and "teaching". In this study, peer is rather different from other research which commonly select the word "colleague" for its definition since plenty of research have proved the significance of POT in the scope of teacher or lecturer profession. In spite of the previous studies, the researcher concerns to promote POT in the context of teacher candidates [8]. Accordingly, the peer is specified as partner in one class who mostly has no teaching experience. The second is "observation or review" which focuses with visible performance of teaching. It means that the observation is conducted through recording aspects in face-to-face teaching performance through teaching rubric. Lastly, teaching means an activity to present the materials designed in the approved lesson plan [9][10]. In short, peer review model in this context refers to mutual observations of pre-service teachers during microteaching lesson. One of the benefits of this model is nonjudgemental, constructive feedback that influence the students motivation for teaching enhancement [7]

\section{METHOD}

This study was carried out in Microteaching class, a compulsory lesson in English Education Study Program, Faculty of Teacher Training and Education, at Universitas Muhammadiyah Sidoarjo. The main objective of the lesson is to review various teaching methods as well as classroom 
management to prepare pre-service teachers in facing the real instruction though mini process of teaching. The participants were selected randomly and involved five students with no teaching experience yet. They consist of three female and two male. Neither had previously contributed in POT. The data collection activities were performed on even semester, 20162017 academic year. The detail activities in POT with Peer Review model stages are adapted from Eri [7], and the steps are decribed as follows.

\section{A. Pre-Observation}

This step begins with negotiating a set of criteria of teaching aspects. The participants consulted the lesson plan together with other students to get feedback in terms of the completeness, arrangement, suitability of the standard competence, material, work sheet, time allotment, and assessment. The curriculum applied based on the current development of Indonesian curriculum, namely Curriculum 2013 which implements Scientific Approach.

\section{B. Peer-Observation}

There were two roles in this stage. The first role is on being an observer. The students had to view their friends very carefully in the back row and try to match the action with the assessment rubric. There were 3 observers did this job. They gave point to reflect the quality of the teaching aspect. The second role is on being observed. In this situation, the students performed in front of the classroom with prepared materials and very tidy appearance that representing a teacher figure. Teaching media they used varied from the simple pictures to PPT slides. For the students who had no role, they became the students based on the observee's target.

\section{Post-Observation}

After conducting the observer role, the students summarized what they assessed and select the significant point to share for the observee's feedback to the next teaching. The feedback covers both positive and negative points of the performance as well as the lesson plan.

\section{Critical Reflection}

The highlighted points finally were expressed by the students to the observees at the end of the performance directly in the class, not via email or other media. This can be beneficial for both observer and observe for clarification session. It also encourages the observer to be more serious in giving constructive feedback and avoid them from playing their gadgets. The lecturer played a role as facilitator in this stage. The second is a self-analysis report for self-reflection. One of the points in this report is commenting the feedback of the observer. It may be supporting or declining written statement.

\section{E. Implementation}

The implementation stage is not yet implemented. However, to follow up the feedback, the students were asked to revise the lesson plan into the more complete form and compile it into one big report. The real teaching can be realized in the following semester, particularly in teaching practicum course.
This POT experience is expected as the reflection for the student teachers to be more confident and well-prepared in giving English instruction.

\section{SElF-AnAlysis RePORT ON ThreE Roles In POT}

To get relevant points from the students' answers that have been explained descriptively, the data is summarized in table 1.

TABLE 1. SUMMARY OF STUDENTS' REPORT ON POT IMPLEMENTATION

\begin{tabular}{|c|c|c|c|}
\hline \multirow{2}{*}{$\begin{array}{l}\text { Particip } \\
\text { ant }\end{array}$} & \multicolumn{3}{|c|}{ Self-Analysis Report } \\
\hline & Being an Observer & $\begin{array}{l}\text { Being an } \\
\text { Observee }\end{array}$ & Being a Student \\
\hline Student I & $\begin{array}{l}\text { - it's not an easy } \\
\text { task } \\
\text { - I had authority to } \\
\text { assess and citisize } \\
\text { - I needed to focus } \\
\text { on the observee } \\
\text { - I had to avoid } \\
\text { subjectivity } \\
\text { through rubric } \\
\text { evaluation }\end{array}$ & $\begin{array}{l}\text { - It's a thrilling } \\
\text { experience } \\
\text { - I must not lose } \\
\text { my "cool" } \\
\text { during the } \\
\text { lesson } \\
\text { - I found unique } \\
\text { distinctive } \\
\text { personalities }\end{array}$ & $\begin{array}{l}\text { - The least } \\
\text { burden from } \\
\text { the three roles } \\
\text { - I could act as I } \\
\text { wanted }\end{array}$ \\
\hline $\begin{array}{c}\text { Student } \\
\text { II }\end{array}$ & $\begin{array}{l}\text { - I must be } \\
\text { objective when } \\
\text { assessing the } \\
\text { teacher } \\
\text { performance } \\
\text { through provided } \\
\text { rubric }\end{array}$ & $\begin{array}{l}\text { - I felt nervous, } \\
\text { but excited } \\
\text { - It's not an easy } \\
\text { job } \\
\text { - I must be patient } \\
\text { and brave to do } \\
\text { silly things } \\
\text { - I needed to } \\
\text { prepare the } \\
\text { appropriate } \\
\text { lesson plan, and } \\
\text { it is exhausting }\end{array}$ & $\begin{array}{l}\text { - I felt enjoyable } \\
\text { - I became a trial } \\
\text { student who } \\
\text { was often } \\
\text { pointed as the } \\
\text { representative } \\
\text { in doing the } \\
\text { teachers'tasks, } \\
\text { it was a crazy } \\
\text { experience }\end{array}$ \\
\hline $\begin{array}{c}\text { Student } \\
\text { III }\end{array}$ & $\begin{array}{l}\text { - That was like } \\
\text { determining the } \\
\text { destiny of } \\
\text { someone } \\
\text { - The criteria list to } \\
\text { assess was helpful } \\
\text { to guide me }\end{array}$ & $\begin{array}{l}\text { - I Felt afraid } \\
\text { before starting } \\
\text { my teaching } \\
\text { - When I involved } \\
\text { inside the } \\
\text { teaching process, } \\
\text { I felt easy }\end{array}$ & $\begin{array}{l}\text { - I learned how } \\
\text { to appreciate } \\
\text { the one who is } \\
\text { teaching in the } \\
\text { class }\end{array}$ \\
\hline $\begin{array}{c}\text { Student } \\
\text { IV }\end{array}$ & $\begin{array}{l}\text { - I could identify } \\
\text { different kinds of } \\
\text { teacher's } \\
\text { characteristic } \\
\text { - I could learn from } \\
\text { the teacher } \\
\text { performance in } \\
\text { term of teaching } \\
\text { method and media } \\
\text { - I had the } \\
\text { opportunity to } \\
\text { give suggestion } \\
\text { for the better } \\
\text { teaching. }\end{array}$ & $\begin{array}{l}\text { - I felt excited to } \\
\text { teach } \\
\text { - I should prepare } \\
\text { the materials } \\
\text { - I knew how to } \\
\text { remind the } \\
\text { students when } \\
\text { they were late } \\
\text { - I could give } \\
\text { interesting } \\
\text { situation through } \\
\text { video }\end{array}$ & $\begin{array}{l}\text { - I felt happy } \\
\text { - I only sat and } \\
\text { listened to } \\
\text { what the } \\
\text { teachers } \\
\text { explained }\end{array}$ \\
\hline $\begin{array}{c}\text { Student } \\
V\end{array}$ & $\begin{array}{l}\text { - It was my } \\
\text { favourite activity } \\
\text { since I am critical } \\
\text { student. I could } \\
\text { express my } \\
\text { comments. } \\
\text { - } \quad \text { I enjoyed giving } \\
\text { some suggestion }\end{array}$ & $\begin{array}{l}\text { - I felt dizzy, } \\
\text { confused, } \\
\text { nervous } \\
\text { - I was afraid of } \\
\text { making bad } \\
\text { presentation }\end{array}$ & $\begin{array}{l}\text { - I was happy to } \\
\text { help my friend } \\
\text { who taught } \\
\text { me and did } \\
\text { the tasks. } \\
\text { - } \quad \text { It was fun } \\
\text { when I got } \\
\text { reward }\end{array}$ \\
\hline
\end{tabular}

The pre-service perspective towards the three different roles in Microteaching Class with POT was described through self-analysis report by answering two questions: 1 . Explain 
your experience when you take a role as: a) teacher; b) observer; c) student. 2. From your teaching performance, explain the things the observers have suggested from their peer-evaluation paper. Do you agree with them? Why.

Reflecting on the students' perspectives in conducting three different roles in the POT, this study draws that it is difficult to give equally maximal contribution to the whole roles. Mostly, the pre-service students responded positively to be the student. They felt comfortable when taught by their own friends. This also similar to peer tutoring where the students teach their peers to deliver the concept of a certain topic. It created unthreatening condition so that the students or tutees were confident to express their ideas when they were pointed to perform the tasks[11]. Classroom situation and immedicacy behavior of the teacher lead to build motivation in learning [12][9][10].

For the observee side, the participants seem to have similar ideas that teaching is not an easy job. Many things to prepare, not only physical appearance, but also teacher behavior as well as lesson plan as the guidance. The words afraid, nervous, dizzy indicate that they are inexperienced teachers. Indeed, there are differences between experienced and inexperienced teacher in some aspects. In the broader scope, previous studies proved that inexperienced teacher tended to be sparse and hierarchically shallow in their perceptual pattern [15] in although similarity is found in the emotional reaction, in stressful situation [16].

Being an observer finds the easy and hard job in the same time. The easy thing appears to the critical students, for they can express what they see frankly to the observee. On the other hand, observers also has special burden to some situation that causes more stress [16], especially for the low proficient students. They need to force themselves to focus on their friends' performance and provide constructive feedback objectively based on the criteria of the rubric to their classmates. To this point, the rubric in POT model is beneficial for guidance since sometime the students will feel confused and guilty when they state a lot of comments based on the subjective point of view. Another benefit for the observer that have not got the teaching turm is that they can learn criteria mentioned in the rubric as well as inspiration from the previous observee's performance to prepare their upcoming teaching.

\section{SElF-AnAlysis RePORT ON CRITICAL FEEBACK}

The next result are related to the five participants diverse impression when they got critical feedback from the observer. It is expressed in the following notes:

\section{Student I}

One of the observers believed that I wasted my time in the early phase of teaching. I disagree with such opinion. I had already set more minutes for it since in my point of view the first 15 minutes is vital for the opening session to determine the whole success of my teaching.

\section{Student II}

The observers said I was good because the learning process was fun. However, I felt still many things need to be improved in the next performance.

\section{Student III}

Most of the observers praised me since my power when I was teaching. I could make the class more cheerful. However, one of the observers reminded me one pivotal thing related to my lesson plan. I missed one of the points stated there. What I was thinking was merely how to be a good teacher, but I ignored implementing my lesson plan which I had prepared before.

\section{Student IV}

I agree with the observers said that I need to be more attractive when teaching. My performance was good, but I forgot to make a joke to cheer up the classroom situation.

\section{Student $V$}

One of the observers said that I used inappropriate media. I did not agree with her. At that time I used cartoon video to teach procedure text, and in my point of view the media was interesting, fun, and relevant with the material.

One more thing that becomes the pre-service teacher's concern is responding the observers' weakness and strength comments. Based on the achieved data, the pre-service teachers state their agreement dan disagreement for some points. From those comments, the success or failure of the performance will be captured implicitly. During this process, there were some debatable ideas in the observees's mind and sometime emotion, particularly when the students gained comments which is not relevant with their own perspective. Another factor that might be the reason is the feedback coming from the good friend. It tends to be less objective. Therefore, in this microteaching class, three observers were doing the duty to bridge the gap between the peers' subjectivity and the reliability of the comments.

Student I view on the importance of opening teacher activity is accepted and justified [17]. In addition, in the literacy program developed in Indonesia, called Gerakan Literasi Sekolah $(G L S)$, each class is suggested to have literacy activity in the first fifteen minutes before the lesson. These facts lead to the students' belief that in starting the lesson, they have to give good impression. However, what the observers said also could be consideration in this context. Implementing quality 15 minutes opening is appropriate in the real class setting. For micro teaching class it should be minimized into 5-7 minutes. Student II felt that statements that the observers said were less objective since she has good friendship relation in the class. Student III focused too much on the performance and forgot some aspects mentioned in his lesson plan. It is not a big deal if the student miss minor component of the activities and can handle the whole process of the class. Instead, if the activities are crucial point, it influences the learning and teaching behavior quality. Students IV admitted her drawback and reflected on herself that she needs to be able provide jokes to cheer up the class. It needs to be paid attention because if the teacher gives much relaxing activities, the seriousness tends to be hard to build. 
Hence, balanced portion is promoted for this. Lastly, it deals with relative perception of media appropriateness. People can say it good or not only based on the suitability between learning objective and teaching materials. In this case video is attractive media to build learning motivation as well as achievement [18].

Learning from different five responses in the observation process, discussion in the last session of the class is highly recommended to clarify some important points regarding to the students performance and arguments. This is also to avoid student complacency that becomes one of the factors in peer observation in addition to conservatism and unfocussed nature [7].

\section{CONCLUSION}

Based on the findings, this research concludes that POT, with peer review model is possibly implemented to the preservice teachers with some adaptation that can be accessed by both the lecturer and the students. Microteaching class is representative for this model since they are prepared to face problems and possibilities in the real class during teaching practicum. Through experiencing the role of teacher, observers, and student, they have started to recognize their position in different situation. Hopefully this practice can increase their awareness to the need of improvement in teaching skill, especially from the reflective feedback and selfcritical report.

For future researchers, it is better to involve the peers as the observers from different class to obtain higher reliability and deeper insight in the observation stage of POT. Then, to realize the perfect steps in POT that have not been carried out in this study, it is suggested to invite the real secondary level students as the participant in microteaching class as the step of implementation stage of POT.

\section{ACKNOWLEDGEMENT}

This study was supported by English Education Study Program (Universitas Muhammadiyah Sidoarjo). Many thanks also go to my beloved students for active contribution in implementing POT during Microteaching course. Lastly, the author thanks the reviewers for constructive comments for insightful ideas to shape this work into a quality writing.

\section{REFERENCES}

[1] J. Hiebert, A. K. Morris, D. Berk, and A. Jansen, "Preparing Teachers to Learn from Teaching," J. Teach. Educ., vol. 58, no. 1, pp. 47-61, Jan. 2007.
[2] J. Bale, "Language Proficiency in an Era of Accountability," $J$. Teach. Educ., vol. 67, no. 5, pp. 392-407, Nov. 2016.

[3] K. Buyukkarci, "Formative Microteaching in Teaching and Foreign Language Anxiety," vol. 18, no. 2, pp. 505-511, 2014.

[4] T. Aminah, "Pre-Service Teachers' Anxiety in the First Teaching Practice in Microteaching Class (PPL 1) in English Teacher Education Department UIN Sunan Ampel Surabaya," 2016.

[5] T. Yoon, "Teaching English though English: Exploring Anxiety in Non-native Pre-service ESL Teachers," Theory Pract. Lang. Stud., vol. 2, no. 6, pp. 1099-1107, 2012.

[6] S. Kavanoz and G. Yüksel, "An Investigation of Peer-Teaching Technique in Student Teacher Development," Int. J. Res. Teach. Educ., vol. 1, no. 3, pp. 10-19, 2010.

[7] D. Gosling, "Models of Peer Observation of Teaching," 2002.

[8] K. Rauch and C. R. Whittaker, "Observation and Feedback during Student Teaching: Learning from Peers," Action Teach. Educ., vol. 21, no. 3, pp. 67-78, Oct. 1999.

[9] T. Mutton, H. Hagger, and K. Burn, "Learning to plan, planning to learn: the developing expertise of beginning teachers," Teach. Teach., vol. 17, no. 4, pp. 399-416, Aug. 2011.

[10] H. Craft and P. D. Bland, "Ensuring Lessons Teach the Curriculum with a Lesson Plan Resource," Clear. House A J. Educ. Strateg. Issues Ideas, vol. 78, no. 2, pp. 88-94, Nov. 2004.

[11] Colin J. Beasley, "Students as teachers: The benefits of peer tutoring," in Proceedings of the 6th Annual Teaching Learning Forum, 1997, pp. 21-30.

[12] J. T. Guthrie and K. E. Cox, "Classroom Conditions for Motivation and Engagement in Reading," Educ. Psychol. Rev., vol. 13, no. 3, pp. 283-302, 2001.

[13] R. C. Gardner, "Language Learning Motivation: The Student, the Teacher, and the Researcher.," Texas Pap. Foreign Lang. Educ., vol. 6 , no. 1 , pp. 1-18, 2001.

[14] D. M. Christophel, "The relationships among teacher immediacy behaviors, student motivation, and learning," Commun. Educ., vol. 39, no. 4, pp. 323-340, Oct. 1990.

[15] S. K. S. Tan, "Differences between Experienced and Inexperienced Physical Education Teachers' Augmented Feedback and Interactive Teaching Decisions," J. Teach. Phys. Educ., vol. 15, no. 2, pp. 151170, Jan. 1996.

[16] D. Yagil, "If Anything Can Go Wrong It Will: Occupational Stress Among Inexperienced Teachers," Int. J. Stress Manag., vol. 5, no. 3, pp. 179-188, 1998.

[17] C. M. Evertson, Classroom management for elementary teachers. Allyn and Bacon, 1994.

[18] S. Stempleski, Video in second language teaching: using, selecting, and producing video for the classroom. Teachers of English to Speakers of Other Languages. 